\title{
Ekosistem Yang Mempengaruhi Pengembangan Pustakawan
}

\author{
Oleh \\ Abdul Rahman Saleh \\ 1,2Perpustakaan IPB University \\ e-mail : abdulr.saleh.2003@gmail.com
}

\begin{abstract}
ABSTRAK
Pendahuluan. Pengembangan perpustakaan sangat dipengaruhi oleh lingkungan pemustaka yang akan dilayaninya. Lingkungan tersebut saat ini dikenal dengan ekosistem VUCA yaitu Volatility, Uncertainty, Complexity dan Ambiguity. VUCA sendiri muncul akibat dari perkembangan teknologi yang saat ini disebut revolusi industri 4.0.

Metode dan Pengumpulan Data. Karya tulis ini merupakan literature review atau tinjauan literatur yang membahas pengaruh ekosistem VUCA dalam pengembangan perpustakaan berdasarkan kepada literatur dan laporan hasil penelitian terkait. Literur dikumpulkan baik melalui daring maupun literatur tercetak kemudian dibahas.

Analisis Data. Berbagai karya tulis yang relevan dengan ekosistem VUCA dikumpulkan dari buku, jurnal, maupun situs web, kemudian dianalisis secara deskriptif.

Hasil dan Pembahasan. Berbagai pengembangan perpustakaan harus mempertimbangkan ekosistem VUCA agar layanan yang diberikan oleh perpustakaan sesuai dengan kebutuhan pemustaka di era revolusi industri 4.0.

Kesimpulan. Perpustakaan termasuk entitas yang sangat dipengaruhi oleh lingkungan atau ekosistem VUCA. Karena itu agar perpustakaan bisa survive di era teknologi desruptive yang menyebabkan VUCA tersebut, maka pustakawan sebagai motor penggerak perpustakaan harus mempunyai terobosan layanan yang bisa keluar dari jebakan VUCA.
\end{abstract}

Kata kunci: Ekosistem, VUCA, revolusi industri 4.0, masyarakat 5.0.

\begin{abstract}
Introduction. The development of a library is strongly influenced by the environment of the users has to be serve. This environment is currently known as the VUCA ecosystem, namely Volatility, Uncertainty, Complexity and Ambiguity. VUCA itself emerged as a result of technological developments which are currently called the industrial revolution 4.0.

Methods and Data Collection. This paper is a literature review that discusses the influence of the VUCA ecosystem in library development based on the literature and related research reports. Literature is collected both online and printed literature and then discussed.

Data analysis. Various papers relevant to the VUCA ecosystem were collected from books, journals, and websites, then analyzed descriptively.

Results and Discussion. Various library developments must consider the VUCA ecosystem so that the services provided by libraries are in accordance with the needs of users in the era of the industrial revolution 4.0.

Conclusion. Libraries are entities that are strongly influenced by the VUCA environment or ecosystem. Therefore, in order for libraries to survive in the era of destructive technology that causes VUCA, the librarian as the driving force of the library must have a service breakthrough that can get out of the VUCA trap.
\end{abstract}

Keywords: Ecosystem, VUCA, industrial revolution 4.0, society 5.0. 


\section{Pendahuluan}

Sejak akhir abad yang lalu atau abad 20 hingga awal abad 21 sekarang ini telah terjadi perkembangan yang luar biasa pesat dari kehidupan manusia. Manusia yang awalnya merupakan makhluk pencari makan dengan cara berburu, saat ini sudah berubah sangat cepat menjadi masyarakat yang kehidupannya berlandaskan kepada pemanfaatan informasi bahkan lebih daripada itu saat ini telah berkembang ke arah pemanfaatan teknologi namun tetap berpusat kepada manusia itu sendiri (Digital Economy, 2019; Weisman, 1972). Untuk mempersiapkan pustakawan dalam menghadapi perubahan situasi dunia yang begitu cepat ini maka kita harus mengenal ekosistem yang berpengaruh terhadap situasi dunia.

\section{Perkembangan Masa/Jaman/Era}

Di dunia ini dikenal dua aliran dalam menyatakan perkembangan jaman (era). Pertama yang didasarkan kepada perkembangan industri dan teknologi, dan yang kedua yang didasarkan perkembangan pola hidup dan cara-cara bermasyarakat. Dari beberapa bacaan kita mengenal era revolusi industri sebagai berikut: era revolusi industri 1.0; era revolusi industri 2.0; era revolusi industri 3.0; dan era revolusi industri 4.0 (IPB, 2019; Digital Economy, 2019).

\section{Revolusi industri 1.0}

Kita tahu dari bacaan sejarah bahwa sebelum era revolusi industri dimulai maka setiap pekerjaan di dunia ini dilakukan menggunakan tenaga manusia dan hewan. Misalnya, pekerjaan menggemburkan tanah di sawah dilakukan dengan menggunakan cangkul oleh tenaga manusia. Paling banter pekerjaan itu dibantu oleh tenaga hewan yang digunakan untuk menarik bajak. Begitu juga ketika manusia melakukan proses menggiling beras menjadi tepung, maka pekerjaan itu dilakukan dengan tenaga manusia yaitu dengan menumbuk menggunakan lesung dan alu. Selain dengan otot, tenaga lain yang biasa digunakan dalam proses produksi kala itu adalah tenaga air dan tenaga angin, misalnya pada mesin penumbuk gandum. Untuk membantu memutar alat atau "mesin" yang cukup berat itu manusia dibantu oleh kincir air atau kincir angin. Masalahnya adalah mesin ini tidak fleksibel. Kita tidak bisa memindahkan mesin tersebut sesuai dengan keinginan kita. Kita cuma bisa menjalankan mesin itu di dekat air terjun jika menggunakan tenaga air atau di daerah yang berangin stabil dan terus menerus jika mesin itu menggnakan tenaga angin. Semua mesin tersebut sangat bergantung kepada alam sehingga kurang bisa diandalkan. Seperti mesin yang bertenaga angin maka jika benar-benar tak ada angin yang bisa digunakan untuk memutar kincir maka mesin tersebut sama sekali tidak bisa beroperasi (Saleh, 2020).

Revolusi Industri yang terjadi antara tahun 1750-1850 ini membuat perubahan secara besar-besaran dalam proses produksi terutama dalam bidang pertanian, transportasi, manufaktur, dan teknologi di mana perubahan tersebut berdampak mendalam terhadap kondisi sosial, budaya serta ekonomi di seluruh dunia (Sasana Digital, 2019). Awal mula revolusi industri ini terjadi di Inggris yaitu dengan penggunaan mesin uap pada mesin tenun mekanis. Revolusi industri ini kemudian menyebar ke seluruh dunia seperti Eropa, Amerika, Jepang, dan lain-lain. Revolusi industri ini telah mengubah proses produksi seperti yang semula semua pekerjaan dilakukan dengan menggunakan tenaga manusia dan hewan, maka dengan ditemukannya mesin uap proses produksi tersebut kemudian dilakukan dengan bantuan mesin uap (IPB, 2019). 


\section{Revolusi industri 2.0}

Revolusi industri yang dimulai di Inggris tersebut telah mengubah banyak hal. Revolusi industri tersebut adalah revolusi industri pertama atau revolosu industri 1.0. Kemudian revolusi industri berikutnya yaitu revolosi industri kedua di awal abad ke-20 juga telah memperbaiki efisiensi proses produksi menjadi lebih baik lagi. Proses produksi memang sudah menggunakan mesin, mulai dari mesin uap dan kemudian mesin bertenaga listrik. Namun, apa yang terjadi di pabrik masih jauh dari kata modern. Di akhir 1800-an, mobil sudah mulai diproduksi besarbesaran dan secara massal. Namun, perakitan mobil masih dirakit mulai awal sampai selesai pada titik yang sama. Seorang perakit memroses barang tersebut dari nol hingga jadi. Setiap mobil akan dirakit oleh seorang perakit yang "Generalis" dari awal hingga selesai (Saleh, 2020).

Proses produksi demikian mempunyai banyak kelemahan seperti perakitan harus dilakukan secara paralel. Untuk merakit banyak mobil, proses perakitan harus dilakukan oleh banyak tenaga kerja, dan setiap tenaga harus menguasai semua proses mulai dari memasang baut sampai memasang mesin. Proses produksi yang seperti ini merupakan proses produksi yang cukup lambat dan memerlukan tenaga ahli yang banyak. Pada masa ini yaitu sekitar tahun 1913 terjadi revolusi yaitu dengan terciptanya Lini Produksi atau Assembly Line. Proses produksi ini menggunakan sistem conveyor belt atau ban berjalan. Proses produksi yang tadinya satu orang mengerjakan seluruh produk berubah menjadi satu produk dikerjakan oleh banyak orang. Proses ini melahirkan spesialis, yaitu satu orang hanya mengerjakan satu bagian saja (IPB, 2019).

\section{Revolusi industri 3.0}

Pada masa revolusi industri 1.0 dan 2.0 unsur manusia masih berperan penting dalam suatu proses produksi, maka pada revolusi industri 3.0 tenaga manusia tersebut banyak digantikan oleh mesin. Mesin yang berpikir secara otomatis. Yaitu mesin yang dikenal dengan komputer dan robot. Pada awalnya komputer merupakan barang mewah. Komputer generasi pertama yang disebut ENIAC adalah sebuah mesin yang sangat besar dengan konsumsi listrik yang juga sangat besar. ENIAC memiliki 17.468 tabung vakum, 7.200 diode kristal, 1.500 pemancar, 70.000 resistor, 10.000 kapasitor dan sekitar 5 juta sambungan yang disolder dengan tangan. Beratnya 27 ton dan ukurannya 2,4 m x 0,9 $\mathrm{m} \times 30 \mathrm{~m}$. ENIAC mengambil luas sekitar $167 \mathrm{~m}^{2}$ dan mengonsumsi energi sebesar 160 kW (Digital Economy, 2019).

Penemuan semi konduktor, kemudian transistor, dan diteruskan dengan penemuan Integrated Circuit (IC) menjadikan ukuran komputer tersebut mengecil. Begitu juga kebutuhan catu daya listriknya semakin kecil, namun dengan kemampuan yang semakin besar. Pada era ini juga terjadi perkembangan perangkat lunak yang mendukung perangkat keras elektronik.

Ukuran komputer yang semakin kecil tersebut memegang peranan penting, karena dengan ukurannya yang kecil itu maka komputer dapat dipasang di mesinmesin produksi. Kemampuan komputer dalam melakukan banyak hal menggantikan banyak peran manusia. Pekerjaan di pabrik banyak digantikan oleh komputer atau robot. Semuanya menjadi otomatis. Pada satu sisi, perkembangan teknologi digital ini mempermudah pekerjaan manusia karena hanya dalam hitungan jam, banyak produk yang dapat dihasilkan. Proses bisnis semakin berkembang pesat dan lebih terstruktur mulai dari tahap perencanaan oleh manusia, jadwal, dan aliran proses produksi. Namun disisi lain, banyak pekerjaan yang tadinya tersedia bagi manusia menjadi hilang karena sudah diganti oleh mesin. 
Revolusi industri 4.0.

Internet yang ditemukan pada era revolusi ketiga menjadi dasar bagi terbukanya pintu Revolusi Industri keempat atau 4.0. Salah satunya adalah pemanfaatan internet (Internet of Thing/IoT). IoT ini berambisi menginterkoneksikan segala perangkat yang ada dengan internet. Saat ini misalnya dengan gawai kita bisa mengetahui kondisi cuaca di suatu tempat karena gawai kita terkoneksi dengan alat pengukur suhu di tempat tersebut, kita juga bisa mengetahui kondisi kepadatan jalan raya karena gawai kita terkoneksi dengan kamera yang ada di jalan raya yang sedang kita pantau kepadatannya, atau kita bisa tahu apakah di jalan tersebut ada kecelakaan atau tidak karena gawai kita terkoneksi dengan kamera di jalan di mana kecelakaan tersebut terjadi, dan seterusnya. Proses produksi pada revolusi industri 4.0 menggunakan konsep otomatisasi oleh mesin tanpa campur tangan tenaga manusia. Hal tersebut merupakan hal vital yang dibutuhkan oleh industri dengan alasan efisiensi, baik waktu, tenaga kerja, maupun biaya. Penerapan industri 4.0 seperti ini dikenal dengan istilah Smart Factory.

Inovasi terus menerus berkembang hingga 2019 ini mulai menggunakan robot di bidang industri. Kecerdasan buatan (Artificial Intelligence) juga mulai masuk dalam proses produksi. Dalam masa Revolusi Industri 4.0 banyak inovasi baru ditemukan. Diantara penemuan tersebut dapat disebutkan seperti internet untuk semua (Internet of Things/ IoT), Big Data, percetakan tiga dimensi, kecerdasan buatan (artificial intelligence/AI), kendaraan yang dikendalikan oleh komputer, rekayasa genetika, robot dan mesin pintar. Hal yang sangat memengaruhi dalam Revolusi Industri 4.0 adalah ditemukannya Internet of Things. Dengan Io'Tnya maka Revolusi industri 4.0 ini sangat berpengaruh kepada ekosistem dunia, termasuk tata cara kehidupan manusia.

\section{Perkembangan jaman berdasarkan pola masyarakat}

Perkembangan masa/jaman/era yang kedua kita kenal dengan nama masyarakat (society) yaitu masyarakat (society)1.0; masyarakat (society) 2.0; masyarakat (society) 3.0; masyarakat (society) 4.0; dan masyarakat (society) 5.0 (Sasana Digital, 2019).

Masyarakat merupakan sekelompok orang yang membentuk suatu sistem di mana sebagian besar interaksinya adalah antar individu yang berada dalam msyarakat tersebut. Kehidupan dan tata nilai masyarakat terus berkembang dari masa ke masa dan perkembangan yang cukup pesat bisa dilihat dengan membandingkan kehidupan masyarakat zaman dahulu dengan masyarakat zaman modern. Adanya masyarakat atau society 5.0 menggambarkan bentuk ke- 5 dari perkembangan msyarakat dalam sejarah perkembangan kehidupan manusia. Perjalanan society 1.0 hingga bisa mencapai society 5.0 dapat dijelaskan sebagai berikut.

\section{Masyarakat 1.0 (hunter \& gatherer society)}

Awal mula manusia mengenal dan membentuk kelompok yang kemudian dikenal dengan masyarakat. Manusia bertahan hidup dan mencari makanan dengan cara berburu binatang liar. Pada waktu itu mereka hidup dengan cara berpindah-pindah atau yang disebut masyarakat nomaden. Bila binatang buruan dan buah-buahan yang menjadi sumber makanan mereka sudah mulai menipis maka mereka akan mencari tempat baru yang masih banyak tersedia makanan untuk diburu. Untuk keperluan perburuan itu manusia sudah bisa membuat berbagai peralatan sederhana dan menggunakan kekuatan alam seperti api untuk memasak dan melindungi diri. 


\section{Masyarakat 2.0 (agricultural society)}

Setelah manusia mengenal cara bercocok tanam dan memelihara hewan/ternak untuk persediaan makanan mereka maka mereka sudah mulai mengurangi kebiasaan berpindah-pindah tempat tinggal atau dengan kata lain mereka sudah mulai menetap dan membangun masyarakat yang lebih kompleks. Masa ini disebut sebagai era pertanian. Manusia fokus mengembangkan cara bercocok tanam sehingga dapat memproduksi hasil pertanian yang menjadi persiaan makanan mereka. Pada masa ini mulai muncul berbagai kerajaan, masyarakat mulai mengenal tulisan, kotakota mulai didirikan.

\section{Masyarakat 3.0 (industrial society)}

Masyarakat yang sudah fokus kepada pertanian dan peternakan mulai membutuhkan hal-hal yang lebih kompleks seperti mulai butuh sandang, pangan dan papan yang semakin meningkat. Berbekal pengetahuan yang mereka miliki maka masyarakat saat itu mulai membangun sentra-sentra produksi atau pabrik untuk memproduksi kebutuhan mereka. Pabrikpabrik tersebut sudah mulai mempekerjakan manusia dan mengenalkan sistem upah.

\section{Masyarakat 4.0 (information society)}

Perkembangan ilmu pengetahuan dan teknologi telah memungkinkan manusia mengenal teknologi komputer dengan segala kelengkapannya. Dengan perkembangan kompouetr dan kemudian internet, maka informasi diproduksi dan diedarkan dengan kecepatan yang tidak pernah dibayangkan oleh manusia sebelumnya. Aliran informasi tersebut demikian cepat dan tidak mengenal batas ruang dan waktu. Pada masa ini maka manusia dengan mudah mendapatkan informasi. Semua langkah dan gerak manusia didasarkan atas informasi yang dia miliki. Jumlah produksi informasi dan kecepatan dan kemudahan memperoleh informasi tersebut berakibat kepada perubahan sosial dan budaya dalam masyarakat. Pada masa ini masyarakatnya disebut dengan masyarakat informasi atau information society. Menurut Wikipedia (Wikipedia, 2020) information society adalah:

"is a society where the usage, creation, distribution, manipulation and integration of information is a significant activity. Its main drivers are information and communication technologies, which have resulted in rapid information growth in variety and is somehow changing all aspects of social organization, including education, economy, bealth, government."

Konsep masyarakat informasi itu sendiri muncul pada awal tahun 1970.

\section{Masyarakat 5.0 (human-centered and technology based society)}

Society atau masyarakat 5.0 adalah penyempurnaan dari society atau masyarakat 4.0. Pada masyarakat 5.0 teknologi menjadi bagian dari manusia itu sendiri. Teknologi bukan hanya untuk berbagi informasi, namun dapat memudahkan kehidupan manusia seharihari. Masyarakat ini menekankan pada kehidupan yang terintegrasi, mudah dan cepat. Dalam masyarakat 5.0 dapat dicontohkan misalnya penggunaan robot di sebuah restoran adalah untuk membantu pekerjaan-pekerjaan di restoran tersebut seperti melayani pengunjung, sedangkan di perpustakaan penggunaan robot juga membantu pustakawan dalam melayani pengunjung perpustakaan. Di rumah maka robot digunakan untuk membantu membersihkan rumah dan lain-lain di mana robot-robot tersebut dapat dikendalikan dengan komputer dan internet. Society 5.0 membuat kehidupan manusia menjadi mudah, namun teknologi tidak menguasai manusia melainkan manusia yang mengendalikan teknologi sehingga mendapatkan kualitas hidup yang baik dan nyaman. 


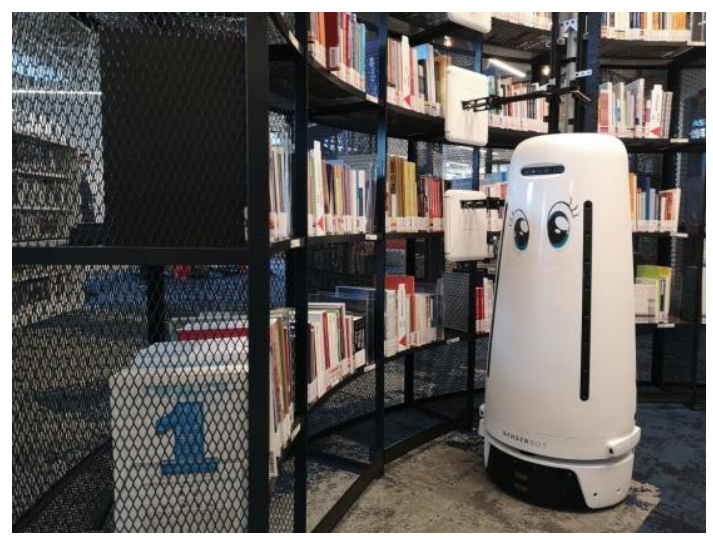

Penggunaan robot di sebuah perpustakaan di Singapura

(sumber: https://portalprobolinggo.pikiranrakyat.com/internasional/pr-78851705/canggihperpustakaan-di-singapura-gunakan-robot-untukmemindai-buku)

\section{Ekosistem VUCA ${ }^{1}$}

Ekosistem VUCA merupakan akibat dari perkembangan teknologi yang memengaruhi perkembangan industri. Perkembangan sudah kita kenal yaitu yang disebut dengan revolusi industri mulai revolusi industri 1.0, revolusi industri 2.0, revolusi industri 3.0, dan terakhir revolusi industri 4.0. Ekosistem VUCA tersebut sangat berkembang pada era revolusi industri 4.0 (IPB, 2019).

Beberapa tahun belakangan ini kita dikenalkan dengan istilah VUCA yaitu kepanjangan dari Volatility untuk V, Uncertainty untuk $\mathbf{U}$, Complexity untuk $\mathbf{C}$ dan Ambiguity untuk A. Istilah ini awalnya populer di lingkungan bisnis yaitu untuk menggambarkan lingkungan bisnis yang makin bergejolak dan kompleks yang menyebabkan bertambahnya ketidakpastian. Menurut Leksana TH (Leksana, 2018): "Istilah VUCA pertama kali digunakan dalam dunia militer pada era sembilan puluhan untuk menggambarkan situasi medan tempur yang dihadapi oleh pasukan di mana informasi medan yang ada amat

\footnotetext{
${ }^{1}$ https://leksanath.wordpress.com/2018/01/27/mengenaldunia-vuca-dan-tantangannya/

sangat terbatas. Bertempur dalam keterbatasan informasi serasa berjalan dalam kebutaan dan bisa menimbulkan chaos. Keadaan ini diistilahkan sebagai medan perang kabut (fog war)".

Pada era 1980an di sekolah bisnis banyak diajarkan cara mengelola situasi bisnis yang relatif mudah diprediksi. Asumsinya adalah rutinitas dan stabilitas. Kemudian kesuksesan bisnis di masa lalu dianalisis kemusian dibuatkan suatu formula yang dijadikan acuan untuk perencanaan di masa depan. Tujuan dan sasaran kinerja direncanakan sebagai strategi perusahaan menggunakan model PDCA atau Plan, Do, Check, Action. Fokus organisasi adalah mengelola sumber daya secara efisien untuk mencapai kinerja. Model ini menjadi kurang relevan dengan tibanya lingkungan VUCA (Volatility, Uncertainty, Complexity and Ambiguity). Seperti arti kata volatile itu sendiri yang menunjukkan gejolak perubahan yang labil dan cepat. Karena cepatnya tersebut maka pebisnis sulit memprediksi apa yang akan terjadi di masa depan. Contoh yang paling baru adalah runtuhnya bisnis ritel besar dan kalah bersaing dengan bisnis daring. Di bidang transportasi juga terjadi hal yang sama di mana transportasi konvensional terengah-engah digilas oleh transportasi online.

Dalam situasi yang tidak menentu kita sulit memproyeksikan siatuasi yang akan datang. Pengambilan keputusan berdasarkan apa yang terjadi di masa lalu justru sering menyeasatkan. Para pemimpin perlu merespons dengan cara yang berbeda. Pengetahuan dan pengalaman masa lalu yang tadinya menjadi modal utama dalam mungkin saja saat ini menjadi kurang relevan. Oleh karena itu tenaga kerja dari masa lalu perlu diberi pelatihan atau reskilling serta peningkatan pengetahuan 
untuk mengubah mindset sehingga dapat servive dalam menghadapi tantangan VUCA. Tim yang sudah mengalami peningkatan skill dan perubahan mindset inilah yang mampu melakukan terobosan.

Dunia kepustakawanan tidak kebal terhadap ekosistem ini. Kondisi VUCA sangat dirasakan juga oleh pustakawan. Pemanfaatan teknologi informasi yang pada awalnya merupakan harapan pustakawan untuk mengembangkan perpustakaan dan teknologi tersebut dapat bertahan lama, sekarang tidak bisa lagi seperti itu. Perkembangan aplikasi komputer yang digunakan oleh perpustakaan begitu cepat menjadi "obsolete". Situasi yang dapat digambarkan adalah seperti ini, perpustakaan yang baru saja mendapatkan anggaran untuk implementasi aplikasi komputer guna meningkatkan sistem pelayanannya, tiba-tiba aplikasi tersebut sudah tidak dapat digunakan lagi karena muncul aplikasi yang baru. Belum lagi persoalan perilaku pemustaka yang sebagian besar merupakan generasi $\mathrm{Z}$ dan milenium atau digital native generation dan net generation. Perilaku dan kebutuhan terhadap informasi mereka sangat berbeda dari generasi sebelumnya. Mereka lebih senang jika informasi tersebut ada dalam genggamannya (mereka biasanya selalu membawa gawai/gadget atau telepon genggam). Dalam hal demikian maka pustakawan harus bisa menyesuaikan pendekatan dan layanan perpustakaannya supaya perpustakaan bisa tetap eksis di tengah pemustaka yang demikian.

Dalam situasi VUCA para pemimpin harus memiliki visi jangka panjang yang jelas. Namun demikian visi tersebut harus fleksibel dan adaptif dalam jangka yang tidak terlalu panjang. Hal ini untuk mengantisipasi perubahan lingkungan yang sangat cepat. Visi jangka panjang tetap diperlukan sebagai alat kontrol pemimpin dalam menjalankan bisnisnya. Namun pendekatan adaptif dan tangkas (agile) menjadi pendekatan yang dapat dilakukan di lapangan. Dalam situasi demikian maka para pemimpin di organisasi yang birokratis akan sulit bergerak lincah. Fenomena ekosistem VUCA ini telah melanda banyak sektor, terutama pada sektor bisnis. Contoh paling fenomenal adalah PHK besarbesaran di pengelola tol. Sebelum masuknya teknologi informasi di bisnis tol maka sektor ini banyak mempekerjakan tenaga manusia, misalnya penjaga pintu tol (melayani pemberian tiket di pintu masuk dan melayani pembayaran di pintu keluar). Ketika di kedua sisi jalan tol ini digunakan mesin, maka terjadilah PHK besar-besaran. Contoh lain masih banyak terjadi, namun demikian masih banyak pelaku usaha yang belum menyadari bahwa mereka terancam dengan kehadiran teknologi ini. Ketika kesadaran atas komplikasi VUCA muncul maka respon mereka sering sudah terlambat.

\section{Volatility:}

Unsur pertama dari VUCA adalah Volatility atau volatilitas. Dalam KBBI Daring volatilitas diatikan sebagai "kecenderungan mudah berubah menjadi gas atau uap dari suatu cairan" (Badan Pembinaan dan Pengembangan Bahasa, 2016). Dari arti kata tersebut maka volatilitas diartikan sebagai lingkungan yang cepat berubah atau labil dan terjadi dalam skala besar. Volatilitas ini sering ditandai dengan munculnya tantangan baru yang sulit diketahui penyebabnya dan tidak memiliki pola yang konsisten. Kondisinya cepat berubah. Sesuatu yang menjadi ancaman setahun atau dua tahun lalu bisa jadi saat ini sudah tergantikan oleh ancaman lain. Proses terbentuknya lingkungan volatilitas ini sangat erat dengan pengaruh teknologi, adanya tatanan ekonomi baru, berubahnya tata nilai dan gaya hidup, serta adanya pertukaran informasi yang cepat, transaksi barang dan jasa dengan trend harga menurun diikuti dengan tingginya 
kecepatan arus perpindahan barang/jasa tersebut. Munculnya transportasi daring dan akomodasi telah menimbulkan goncangan terhadap kemapanan bisnis taksi dan perhotelan. Aplikasi seperti Grab dan Gojek serta varian layanannya seperti gosend, gofood, dan layanan sejebis lainnya telah mengguncang pemain lama di bisnis angkutan dan transportasi. Munculnya Airbnb telah menjadi solusi bagi para wisatawan yang membutuhkan penginapan dengan harga bersahabat, dan kualitas baik. Perencanaan yang fleksibel dan adaptif menjadi kata kunci penting dalam menjalankan bisnis masa kini dan masa depan. Perusahaan dengan struktur tambun dan kaku mulai akan mengalami kesulitan dalam bermanuver. Banyak contoh perusahaan besar yang gulung tikar karena manajemennya kurang fleksibel dan adaptif dalam menghadapi perubahan lingkungan. Kecepatan merespons, keakuratan membaca situasi perubahan yang sedang terjadi merupakan kunci sukses sebuah bisnis. Pola lama yang masih melihat senioritas dengan kekuasaan sebagai model manajemen tidak lagi relevan di masa disruptive ini, alih-alih sebagai alat manajemen menuju sukses malah menjadi penghambat terbesar untuk menghasilkan terobosan dan kreativitas.

\section{Uncertainty:}

Ketidak pastian atau uncertainty adalah suatu situasi atau keadaan yang sulit diprediksi. Dalam Cambridge Dictionary Online (Cambridge University Press, 2020) unacertainty diartikan sebagai " a situation in which something is not known, or something that is not known or certain". Situasi seperti ini tentu menjadi momok bagi para pelaku bisnis atau kegiatan lain. Tidak pastian lingkungan merupakan kondisi umum yang menjadi bagian keseharian kita. Berita global sangat cepat mengalir ke lingkungan rumah kita. Misalnya bagaimana Trump menjadi presiden US ke-45 pada akhir tahun 2016 adalah hal yang tidak diprediksi oleh para pengamat politik. Kekalahannya pada akhir 2020 juga mempengaruhi ekonomi dunia. Hubungan politik yang menghangat antara Amerika dengan China sangat berdampak pada pelemahan mata uang dan bursa saham di berbagai belahan dunia. Masih banyak situasi tidak pastian yang terjadi di lingkungan kehidupan kita. Kondisi alam seperti kekeringan, perubahan cuaca ekstrim serta bencana alam dalam sepuluh tahun terakhir telah mengancam stabilitas pangan dunia. Harga komoditas sembilan bahan pokok yang tidak stabil menjadi berita keseharian kita, misalnya tiba-tiba harga daging naik tidak terkendali, begitu juga harga cabai. Hanra minyak dunia yang turun padahal selama ini terus naik merupakan contoh lain dari lingkungan yang tidak pasti. Imbas berlapis dari kondisi ini mengakibatkan tingkat uncertainty yang tinggi.

\section{Complexity:}

Complexity atau kompleksitas menggambarkan keadaan lingkungan yang kompleks. Cambridge Dictionary (Cambridge University Press, 2020) mengartikan complexity adalah "the state of having many parts and being difficult to understand or find an answer to". Tantangan menjadi lebih rumit karena berbagai faktor yang saling terkait. Dalam situasi ekosistem VUCA kita sulit memahami penyebab suatu masalah secara langsung. Saling keterkaitan dari berbagai kejadian menjadi penyebab yang saling mempengaruhi satu sama lain mengakibatkan timbulnya suatu masalah. Penyebab kompleksitas bisa berasal dari berbagai banyak faktor sekaligus seperti: munculnya kompetitor, perkembangan teknologi, beralihnya pola konsumsi, adanya aturan baru, perubahan pola pasokan, dan lain-lain. Pemecahan masalah yang tadinya disangka sangat relevan tiba-tiba menjadi usang. Bahkan ketika mencari penyebab suatu masalah, malah menemukan hal baru yang semula 
tidak diperhitungkan. Dalam menghadapi kompleksitas ini kita membutuhkan kearifan dalam melihat setiap komponen pelaku sistem. Mungkin saja penyebab masalah tersebut bahkan muncul dari diri kita sendiri atau dari dalam organisasi. Pada organisasi yang menggunakan pola senioritas dan gaya kepemimpinan paternalistik yang lebih mengendalikan akan melemahkan respons terhadap komplek-sitas tantangan. Tetapi pola selalu melihat masalah selalu datang dari luar juga tidak selalu baik karena pola demikian justru menyebabkan ketegangan baru dalam organisasi. Seringkali terjadi personel lapangan yang memberikan laporan situasi kepada atasan tidak direspon sehingga personil tersebut menjadi kecewa. Komplek-sitas lingkungan tentu memerlukan perbaikan pola kepemimpinan. Terkadang justru atasan menjadi salah satu mata rantai penyebab persoalan yang muncul sebagai kompleksitas VUCA.

\section{Ambiguity:}

Pengertian ambiguity dalam Cambridge Dictionary (Cambridge University Press, 2020) adalah "the fact of something having more than one possible meaning and therefore possibly causing confusion". Ketidak-jelasan bisa juga disebut membingungkan. Menurut Leksana (Leksana, 2018) "bisa diumpamakan seperti melihat melalui kaca buram yang membuat para pembuat keputusan kesulitan memandang apa yang ada. Ambiguity ditandai dengan kesulitan mengkonsepsikan tantangan yang ada dan memformulasikan model solusinya."

Ketika kondisi lingkungan dalam keadaan tidak pasti maka pimpinan akan sulit mengambil keputusan. Contohnya ketika perpustakaan dihadapkan kepada apakah sudah waktunya beralih kepada langganan jurnal online atau tetap pada jurnal tercetak, maka perpustakaan dihadapkan kepada kondisi tidak pasti, karena di satu sisi perpustakaan menghadapi tuntutan sebagian pemustaka yang menghendaki jurnal online, namun sebagian lagi justru mempertahankan jurnal tercetak. Sementara kondisi anggaran terus menurun. Begitu juga perpustakaan menghadapi pilihan apakah akan mengembangkan perpustakaan digital atau tetap pada perpustakaan konvensional mengingat keterbatasan anggaran dan SDM yang menguasai teknologi informasi dan komunikasi. Sekali beralih ke perpustakaan digital, maka perpustakaan tersebut harus menyediakan anggaran dan SDM untuk operasionalisasi dan pemeliharaan perpustakaan digital tersebut. Artinya kita menghadapi suatu pilihan yang sulit memastikan jawaban pastinya. Kondisi lingkungan yang ambigu tersebut seperti kita melihat lingkungan sekeliling yang berkabut. Pandangan kita tidak jernih karena terhalang kabut.

Karena ekosistem VUCA ini memiliki karakter tantangan adaptif, maka pemimpin perlu mengembangkan kemampuan adaptif sehingga bisa mengikuti dan mengelola arus VUCA di lingkungannya. Saling percaya antara piimpinan dengan bawahan sangat diperlukan dalam menyikapi ekosistem VUCA ini. Dengan sikap saling percaya maka akan terjalin kerjasama yang baik antara pimpinan dan bawahan.

\section{Peran pustakawan ke depan:}

Selama puluhan tahun masyarakat mengenal pustakawan sebagai petugas yang melayani peminjaman buku di perpustakaan. Pemahaman ini mirip dengan petugas kios penyewaan buku cerita dan komik yang marah di tahun 60-70an. Pada saat itu jika masyarakat membutuhkan buku cerita dan atau buku komik akan datang ke tempat penyewaan komik tersebut. Mereka akan dilayani oleh petugas yang "mirip" pustakawan. Mengapa disebut mirip pustakawan? Sebab saat itu pekerjaan pustakawan memang sama dengan petugas yang melayani penyewaan tersebut. Pekerjaan pustakawan ini sebetulnya sudah 
berkembang. Tidak lagi hanya melayani pemustaka yang akan pinjam buku ke perpustakaan. Sudah banyak pekerjaan pustakawan yang ditambahkan. Pustakawan di universitas juga bisa membimbing mahasiswa melakukan pemeriksaan anti plagiarisme, bahkan dapat memberikan saran untuk menurunkan tingkat kemiripan karya tulis pemustaka. Di perpustakaan umum sekarang dikenal layanan perpustakaan berbasis inklusi sosial. Pustakawan selain menyediakan informasi dalam meningkatkan taraf hidup pemustaka, mereka juga bisa membimbing melakukan sesuatu aktivitas yang dapat meningkatkan pengetahuan pemustaka sehingga pemustaka tersebut dapat meningkatkan taraf hidupnya. Berikut adalah perkembangan tugas-tugas pustakawan.

\section{Negosiator}

Komunikasi pustakawan kepada pemustaka dalam rangka memberikan layanan perpustakaan dalam rangka penemuan kembali sumber informasi membutuhkan keterampilan sosial. Keterampilan sosial menjadi salah satu syarat wajib bagi interaksi tersebut, di samping tentunya syarat-syarat yang lain. Keterampilan Sosial (Social Skills) adalah kemampuan untuk mengolah dan menata emosi dengan baik ketika interaksi berlangsung. Dalam interaksi tersebut kita harus bisa membaca situasi dan jaringan sosial, berinteraksi dengan lancar, menggunakan keterampilan tersebut untuk mempengaruhi dan memimpin, bermusyawarah dan menyelesaikan perselisihan, serta untuk bekerja sama dan bekerja dalam tim.

Zulaika dalam suatu artikelnya memberikan ilustrasi mengenai pengertian keterampilan sosial yaitu pada sekitar tahun 1970-an, di tengah maraknya protes mahasiswa sedunia menentang Perang Vietnam, seorang pustakawati di sebuah kantor US Information Agency di luar negeri menerima kabar buruk yaitu sekelompok mahasiswa mengancam akan membakar perpustakaannya. Reaksinya pustakawan ini di luar perhitungan. Alih-alih melakukan konfrontasi terhadap pengancam dia malah mengundang kelompok yang mengancam tersebut menggunakan fasilitas perpustakaan untuk menjadi tempat pertemuan mereka. Di sini yang terjadi adalah dialog bukan konfrontasi. Pustakawan ini dengan cerdik telah memanfaatkan hubungan pribadinya dengan beberapa tokoh mahasiswa setempat yang dapat dipercaya dan mempercayainya. Langkah tersebut telah membuka saluran baru yang saling memahami dan ini memengaruhi persahabatannya dengan para tokoh mahasiswa. Perpustakaan itu akhirnya selamat dari pengrusakan. Pustakawan ini telah memperagakan keahliannya sebagai negosiator, penengah, atau agen perdamaian yang sangat hebat, yang mampu membaca memuncaknya ketegangan, mendadaknya perubahan situasi, kemudian mengelola tanggapan dengan menyatukan semua orang bukannya saling mempertentangkannya. Kantor terhindar dari kerusakan seperti yang menimpa kantor-kantor perwakilan Amerika lain yang dipimpin oleh orang-orang yang kurang memiliki keterampilan sosial (Zulaikha, 2019).

Layanan referensi ini biasanya bersifat personal. Nah, dalam era industri 4.0 maka profesi yang dapat bertahan karena tidak dapat digantikan oleh mesin adalah profesi yang menyediakan layanan bersifat personal dan yang perlu pemikiran. Di sinilah pustakawan bisa memainkan perannya agar pustakawan dapat bertahan dari gempuran teknologi disruptive. Layanan referensi ini kita bisa kembangkan seperti berikut:

Pembimbing dalam penelusuran informasi. yaitu memberikan bimbingan literasi yang memungkinkan peserta didik dapat mengembangkan strategi pencarian dan pemanfaatan berbagai alat penemuan 
sumber informasi spesifik pada sebuah bidang ilmu. Di sini peserta didik diberi bimbingan cara-cara penggunaan basis data untuk menemukan sumber informasi terbaik guna menyelesaikan tugas-tugasnya yang terkait dengan pendidikan dan penelitian. Mahasiswa diarahkan agar dapat menetapkan kebutuhan informasinya dan dibimbing untuk membuat strategi pencarian yang efektif untuk menghasilkan serangkaian hasil penelusuran yang relevan.

Pembimbing dalam menyusun pertanyaan dan mengevaluasi informasi, yaitu memberikan literasi yang memungkinkan peserta didik untuk menganalisis, mengevaluasi, menafsirkan dan berpikir kritis tentang informasi. Bimbingan ini akan memberikan kesadaran akan tujuan, kekuatan dan kelemahan berbagai sumber informasi dan mempertimbangkan berbagai pertanyaan yang dapat digunakan untuk membantu mereka mengevaluasi informasi yang akan digunakan.

Pembimbing dalam menciptakan informasi, adalah pemberian literasi yang memungkinkan peserta didik untuk memadukan ide dan menangkap pengetahuan baru. Pustakawan memberikan beberapa tips untuk memulai menyusun informasi baru dengan membuat presentasi yang efektif dan memberikan kesempatan untuk menjelajahi berbagai perangkat lunak presentasi.

Pembimbing dalam memahami informasi, adalah pemberian literasi yang memungkinkan peserta didik untuk menemukan makna dan menerapkan konteks. Pustakawan hendaknya dapat memberikan ikhtisar tentang manfaat, fungsi-fungsi, dan aplikasi sebuah buku elektronik. Dengan demikian diharapkan peserta didik dapat memanfaatkan koleksi buku yang tersedia secara daring (Online) dengan efisien dan efektif yaitu menggunakan fungsi-fungsi seperti menandai dan memberi catatan (anotasi).

\section{Pembimbing dalam penulisan daftar} pustaka (referensi) adalah pemberian literasi yang memungkinkan peserta didik untuk menghargai pekerjaan orang lain, membangun analisis mereka sendiri atas pengetahuan yang ada. Pustakawan perlu memperkenalkan konsep plagiarisme dan memberikan panduan tentang cara mengutip secara efektif. Peserta didik juga perlu dikenalkan dengan aplikasi yang berguna untuk proses ini. Pustakawan perlu memberikan tips tentang bagaimana cara menghindari plagiarisme, mengenalkan tujuan referensi, dan memberikan kesempatan untuk berlatih referensi dalam gaya penulisan di lingkungan perguruan tingginya. Peserta didik perlu diberikan gambaran umum tentang perangkat lunak manajemen referensi (misalnya Mendeley) dan cara memanfaatkannya sebagai referensi dengan cepat dan efisien.

Membimbing dalam mengomunikasikan informasi. Yang dimaksud di sini adalah literasi yang memungkinkan peserta didik mampu membuat ringkasan dan menyebarkan hasil pekerjaan dan gagasannya secara efisien menggunakan media yang tersedia, seperti blog, infografis, dan lain-lain.

Konsultan informasi. Kemampuan memberikan konsultasi ini sangat diperlukan dalam memediasi pemustaka dalam mendapatkan informasi yang dibutuhkan. Di negara maju praktik ini disebut sebagai readers adviser. Tugas dari konsultan informasi ini adalah membimbing mahasiswa dalam melacak informasi untuk kepentingan penelitiannya. Kompetensi yang Diperlukan oleh Pustakawan

Agar supaya layanan perpustakaan yang diberikan dapat memenuhi kebutuhan dan tuntutan pemustaka saat ini atau pemustaka yang hidup di era industri 4.0, maka pustakawan yang menjadi motor utama 
penggerak perpustakaan, selain memiliki kompetensi dasar kepustakawanan dia juga harus memiliki kemampuan lain seperti berikut (Saleh A., 2019):

Kemampuan dan penguasaan terhadap teknologi informasi dan komunikasi.

Kemampuan ini tentunya untuk mendukung pustakawan dalam memberikan layanan perpustakaan yang semakin memerlukan teknologi informasi dan komunikasi. Pekerjaan-pekerjaan perpustakaan yang sangat dasar pun saat ini memerlukan kompetensi TIK tersebut. Apalagi tugas-tugas terkait dengan repositori; bimbingan penggunaan berbagai aplikasi, seperti penggunaan aplikasi anti plagiarisme; penggunaan buku dan jurnal elektronik dan lain-lain sangat memerlukan pengetahuan dan kemampuan TIK.

Pengetahuan dan keterampilan terhadap TIK yang paling dasar harus dikuasai oleh pustakawan seperti menjalankan komputer dan menggunakan sistem operasi (operating system seperti Windows), penggunaan aplikasi pengolah kata (MS-Word), spreadsheet, dan PowerPoint. Bagi perpustakaan yang sudah melanggan jurnal daring (Online Journals), aplikasi pengecekan kemiripan seperti Turnitin, buku elektronik, dan lainlain, maka tidak boleh tidak pustakawan yang mengoperasikan layanan tersebut harus menguasainya.

\section{Kemampuan melakukan penelitian/ pengkajian.}

Pustakawan dalam hal ini harus memiliki kemampuan dan penguasaan metodologi penelitian. Kemampuan tersebut sangat diperlukan, terutama untuk mendukung tugas-tugas pustakawan yang berhubungan dengan analisis informasi. Misalnya saja, pustakawan harus mampu meneliti tren (kecenderungan) arah penelitian di universitasnya, melakukan pemetaan informasi bidang ilmu yang menjadi obyek penelitian para mahasiswa dan dosen di universitasnya. Kemampuan ini sangat diperlukan ketika pustakawan melakukan Collaborative Partnership dengan dosen, peneliti, dan/atau profesor. Banyak pustakawan yang justru terlibat dalam penelitian bersama dosen dan peneliti senior. Bahkan pustakawan sering menjadi nara sumber ketika dosen atau peneliti akan menerbitkan publikasi ilmiahnya. Pustakawan juga sering membantu dosen dalam mengajar (co-teaching), terutama terkait metodologi penelitian, dengan memberikan materi literasi informasi kepada mahasiswa.

\section{Kemampuan berkomunikasi secara prima.}

Dalam memberikan konsultasi atau mediasi maka pustakawan harus memiliki kemampuan komunikasi yang baik terutama ketika harus menyampaikan informasi hasil penelitiannya kepada para pemangku kepentingan di universitasnya. Kemampuan ini sangat penting karena komunikasi yang tidak baik dapat menimbulkan salah persepsi bagi yang menerimanya. Informasi yang baik bila disampaikan secara baik akan menghasilkan penerimaan yang baik. Sebaliknya, informasi baik tersebut bila disampaikan dengan cara yang tidak baik justru tidak akan diterima oleh klien perpustakaan yang dalam hal ini diharapkan sebagai partner pustakawan. Penerimaan yang tidak baik tersebut malah dapat menurunkan kredibilitas pustakawan di mata para pemustaka yang meru-pakan dosen dan peneliti.

\section{Kemampuan mengajar.}

Saat ini banyak perpustakaan yang memiliki program literasi informasi. Dalam program literasi tersebut pustakawan harus menyampaikan materi di depan para pemakai yaitu para mahasiswa, bisa tingkat sarjana atau pasca sarjana. Mungkin juga pustakawan harus menyampaikan literasi informasi tersebut kepada dosen. Oleh karena itu maka pustakawan harus dibekali 
dengan kemampuan mengajar, terutama pustakawan yang ditugasi menyampaikan bimbingan dan juga dalam melakukan literasi informasi kepada peserta didik. Tanpa kemampuan mengajar yang baik walaupun pustakawan tersebut menguasai teknik-teknik literasi dia akan kesulitan dalam menyampaikannya kepada para peserta didik, apalagi peserta didik di lingkungan universitas.

\section{Kemampuan menulis.}

Kemampuan ini sangat diperlukan dalam menyampaikan hasil-hasil kajiannya, terutama yang terkait dengan kebutuhan informasi para pemangku kepentingan perpustakaan universitasnya.

Kemampuan mengemas informasi.

Produk-produk dan jasa perpustakaan seperti abstrak, indeks, tinjauan literatur, pathfinder, panduan literatur dan informasi sekunder lainnya akan sangat memerlukan kemampuan ini.

\section{Kemampuan menyusun rencana strategis.}

Pustakawan terutama pustakawan senior tentu ikut serta dalam proses penyusunan rencana perpustakaan, khususnya rencana strategis. Artinya pustakawan harus memiliki kompetensi manajerial terkait

\section{Daftar Pustaka}

Badan Pembinaan dan Pengembangan Bahasa. (2016). volatilitas. Diambil kembali dari KBBI Daring: https://kbbi.kemdikbud.go.id/entri/volatilitas

Cambridge University Press. (2020). Cambridge

Dictionary. Diambil kembali dari Cambrigdge

Dictionary Online:

https:/ / dictionary.cambridge.org/dictionary/e nglish/supply-chain

Digital Economy. (2019, Mei 7). Mengenal Revolusi Industri dari 1.0 hingga 4.0. Diambil kembali dari Warta Ekonomi.co.id: https://www.wartaekonomi.co.id/read226785/ mengenal-revolusi-industri-dari-10-hingga-40

IPB. (2019). IPB 4.0: Pemikiran, Gagasan, dan Implementasi. (A. Safari, A. E. Aruman, \& E. Anggraimi, Penyunt.) Bogor: IPB Press. penyusunan rencana strategis perpustakaannya terutama dalam hal penyiapan layanan yang akan diberikan kepada para pemustaka sebagai pemangku kepentingan perpustakaan. Setiap kelompok pemangku kepentingan tersebut tentu memiliki kebutuhan informasi yang berbeda dan harus dipenuhi oleh pustakawan di perpustakaannya. Kemampuan mengelola informasi.

Mengelola informasi sebagai pengetahuan (knowledge) dan memanfaatkannya secara optimal untuk menghasilkan publikasi ilmiah bermutu dan terbaru.

\section{Kemampuan melakukan telaah sistem kepustakawanan.}

Sebagai bagian dari manajemen maka pustakawan harus memiliki kemampuan am menelaah sistem kepustakawanan. Kemampuan ini tentunya terkait pengembangan layanan perpustakaan. Sebagai pengendali mutu dalam operasionalisasi perpustakaan, pustakawan harus dapat membantu pimpinan perpustakaan dalam monitoring dan evaluasi manajemen perpustakaan, agar perpustakaan dapat terus berkembang maju (continuous improvement) memenuhi tuntutan para pemangku kepentingan.

Leksana, T. (2018, January 27). Mengenal Dunia VUCA dan Tantangannya. Diambil kembali dari Leksana TH: Executive Coaching Organisation Transformation Leadership Mindset and Capability: https://leksanath.wordpress.com/2018/01/27 /mengenal-dunia-vuca-dan-tantangannya/

Saleh, A. (2019). Rekonstruksi Peran Perpustakaan Sebagai Respon terhadap Kebutuhan Pemangku Kepentingan Perguruan Tinggi. Jakarta: Perpustakaan Nasional RI.

Saleh, A. R. (2020). Perpustakaan dan Pustakawan di Era Revolusi Industri 4.0: Perspektif Perpustakaan Perguruan Tinggi. Bogor: Forpustaka IPB.

Sasana Digital. (2019, Juli 12). Mengintip Perkembangan Revolusi Industri Mulai Era 1.0 
Sampai 4.0. Diambil kembali dari Sasana Digital: https://sasanadigital.com/mengintipperkembangan-revolusi-industri-mulai-era-1-0sampai-4-0/

Weisman, H. M. (1972). Information Systems, Services, and Centers. New York: Becker and Hayes.

Wikipedia. (2020). Information Society. Diambil kembali dari Wikipedia: the free encyclopedia:
https://en.wikipedia.org/wiki/Information_so ciety

Zulaikha, S. R. (2019). "Assertive Librarian" dan tantangan perpustakaan di era revolusi industri 4.0 dalam penyediaan sumber-sumber informasi bagi pemustaka. . Dalam IISIPI, Buku Antologi Kajian dalam Bidang Ilmu Perpustakaan dan Informasi: Filosofi, Teori, dan Praktik (hal. 104-118). Jakarta: IISIPI. 